\title{
蛍光ランプヘの水銀合金の応用
}

\author{
専門会員 広田 泰輔*
}

\section{Fluorescent Lamps using a Mercury Dispenser}

Taisuke Hirota (Fellow Member)

\begin{abstract}
As a rule, fluorescent lamps are filled with mercury and argon. As regards mercury dosiny into the bulb, the method which drops a few drops of liquid mercury through the exhaust tube has been employed. Such conventional method in production is of advantage to exhaust the gaseous impurities from the bulb but causes various defects of quality and characteristic. To eliminate such disadvantages, a manufacturing method which uses a mercury dispenser such as a strip mounted around the etctrode and releases mercury within the tube by means os R. F heating after sealing is introduced. Advantages using mercury dispenser are as follows:

(1) The quantity of mercury enclosed in the lamp is very precise.

(2) The pressure fluctuation of argon fill can be reduced, therefore it is possible to reduce the fluctuation of lamp life and to increse its average life.

(3) In addition, if the new production process is applied for conventional mercury dosing method it is possible to decrease the mercury contents of lamp.
\end{abstract}

\section{1. ま え がき}

监光ランプが害用化されて約半世紀になるが，高効率・長寿命 の光源として，現在わが国では光源生産高の43\% (822億円/年) ${ }^{1)}$ を占める主流製品となって括り, 省エネルギー面から社会的に大 きな寄与をしている.

一方, 周知のと扣り現在の蛍光ランプは発光原理上ランプ内に 水銀と希ガスが封入されている. この水銀の封入方法は一般に液 状の水銀粒を製造工程中に滴下するか，希ガスで送り込む方法が とられている.このような方法では発光要素である水銀を封入す るといら本来の目的以外に, ランプの品質である安全, 信頼性, 珄能に種々の影響を与える.

まず第 1 亿必要定量の水銀を封入することが困難であり，大部 分のランプには必要量以上の水銀が封入される.これは, 省資源 面はもちろん, 廃ランプの環境への影響をより安全にすることか ら改善の努力が必要となる.

第 2 に, ランプの信頼性, 性能に直接関与している希ガス封入 量の大きな変動原因になっているといらことである.

この解決策として新しい製造法が種々提案されているが2) 6), ここでは，その一つである水銀合金法の実用化に伴う技術的諸問 題について娭討を行なった. さらにこれらの技術を活用すること により水銀合金法によらず，精度の高い水銀の定量封入が可能と

* 陎立製作诉青梅工場
なる・

\section{2. 蛍光ランプの有用性}

蛍光ランプの有用性については改めて述べる必要もないが，そ の現状について整理してみる. 一般照明用の各種光源をその効摔 と平均演色評価数によって分類すると図 1 のと扔りとなる. そ れぞれ代表的品種の寿命・価格を図中に記したが，このような単 純な比較でも蛍光ランプは高効率, 高品質で経済的な光源であ

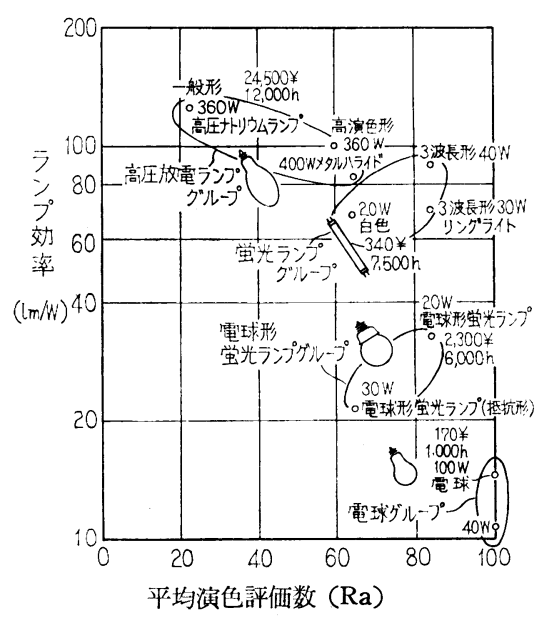

图 1 各種光源の効率と平均演色評価数 


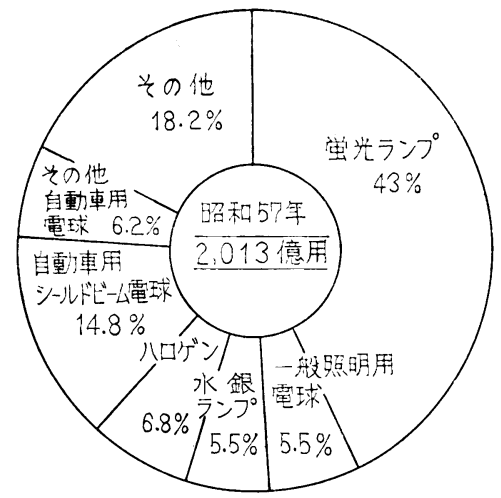

因 2 昭和 57 年電琙類販売高内訳

ることがわかる

図 2 は各種電球類の販売高内訳であるが1), 蛍光ランプが光 源の主流であり，さらに図 3 に示すごとく需要も者车にのびて いることがわかる. 図 4 は日本の住宅に和けるランプ使用の先 態》であるが，仮りにこのような住宅で蛍光ランプによる明るさ を電球で補うとすれば*，每月 $86.5 \mathrm{kWh}$ の追加電力が必要とな りこれは経济的にも約 2,600 円の負担增に相当寸る.

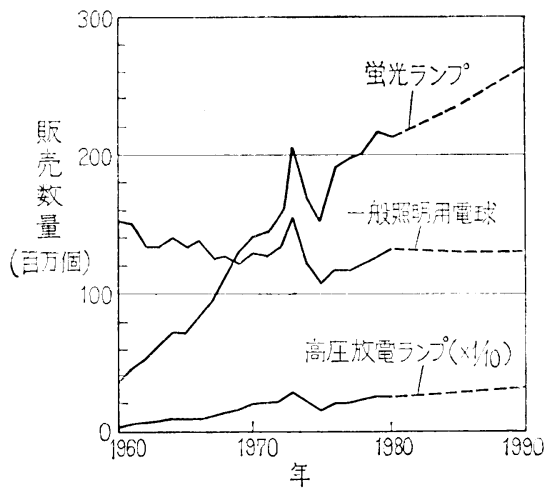

図 3 主要光源の国内需要の推移

（注） 1. 通産少生産動焦統計調查による.2. 1985 拉よび1990年数值法，CIE TC4.9/照时経济 调査国内委只会の見通しによる.

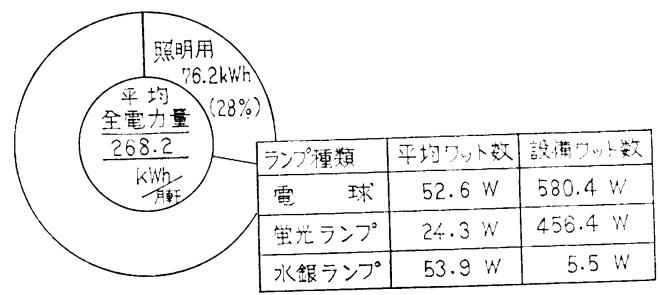

因 4 住宅に拈ける照明用光源の实態

な招，現在の蛍光ランプは水銀を発光要素としているが，この 水銀に代わる代替方式についても検討されて㧊り ${ }^{8)}$, 最も効率の 高いカドミウム励起を利用する場合でも理論的に $46 \mathrm{~lm} / \mathrm{W} し か$ 得られず, 現在の监光ランプが $40 \mathrm{~W}$ ですでに $88 \mathrm{~lm} / \mathrm{W}$ のものが 市販されている状況から，実用的な無水銀蛍光ランプの垁現はき わめて期待が薄いといわれている。すなわち, 現在の蛍光ランプ は実用的にきわめて有用性が高いといえる。

* 蛍光ランプのシステム奻率 $50 \mathrm{~lm} / \mathrm{W}$, 電球 $14 \mathrm{~lm} / \mathrm{W}$ とし, 設借ワット数に比 例して使用されていると仮定した計算.

\section{3. 蛍光ランプと水銀との関連}

\section{1 蛍光ランプの必要水銀量}

現在の蛍光ランプは，原理上水銀放電での共鳴線を利用してい るが，理論的な水銀必要量はどの程度であろらか．水銀蒸気放電 での共鳴線 $(185,253.7 \mathrm{~nm})$ 発生効率は $40^{\circ} \mathrm{C}$ に相当する水銀蒸 気圧 $6.08 \times 10^{-3}$ Torr で最大であり ${ }^{9)}$ ，一般に蛍光ランプは周囲 温度 $20 \sim 25{ }^{\circ} \mathrm{C}$ でこのような条件になるよう設計されている.こ の蒸気压に相当する水銀飽和濃度は $62.5 \mathrm{mg} / \mathrm{m}^{3}$ となり, 通常の $40 \mathrm{~W}$ 蛍光ランプの体積から計算すると, 必要な水銀量は 0.055 $\mathrm{mg}$ となる. しかし，現実にこの程度の量では早期に水銀久乏に よる短寿命現象を起こす。すなわち，実際のランプでは次のよう な要因により水銀が消費される ${ }^{10)}$.

（1）ランプ製作時の残留不純ガスが，水銀と化学的に結合しラ ンプ管壁上に酸化水銀などで沈積物を作る.

（2）電極の電子放射物質が，ランプ点灯中蒸散分解後その成分 である酸素が水銀と化合し酸化水銀となって管壁に沈積する.

（3）水銀イオンが蛍光体粒子中に浸入し，监光体成分との間に 化合物を作る.

（4）ガラス管成分から析出するナトリウム分が，水銀と結合し て合金苂作る。

これらを实際のランプについて推足訣算することは，関与する 要因が妾わめて多く，正確さへの期得が少ないといわれている. また，実験による実際の必要量に関する計算式なども種々提案さ れているが1112，主なものを示すと図 5 のと物りとなる。これ らのことから，一般には点灯条件沈どの変動要因を加味して 40 $\mathrm{W}$ ランプの場合，実用必要量は約 $10 \mathrm{mg}$ とされている.

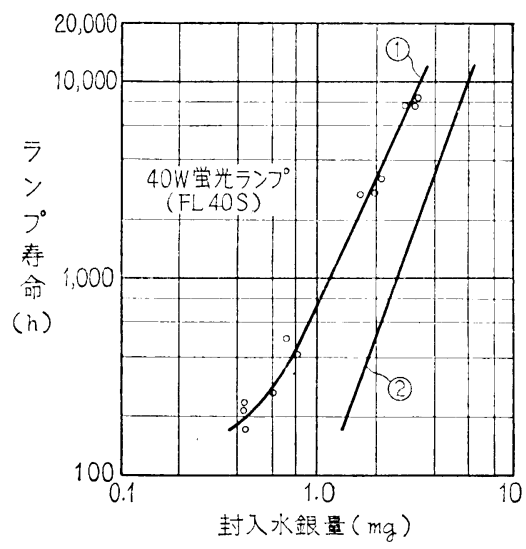

图 5 监光ランプの封入水銀量之水趾火之

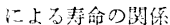

（泣）(1) 昭和53年度電気器具中の重金屈の程年

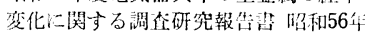
6 月䉓球工業会 p. $1 \sim 5$

(2) J. Light \& Vis. Env. Vol. 1 No. 1 1977 p. 2

\section{2 品質との関連}

従来の一般的製造工程の概要は図 6 のと和りであり，水銀の 影響は排気工程で生じその内容は次の二つになる。

\section{（1）封入水銀量が一定でなく必要以上に封入される}

排気工程で液状水銀を封入する場合, 通常ランプは排気脱ガス 操作のため $450^{\circ} \mathrm{C}$ 程度の高盜状態にあるが, この状態下で液状水 銀が封入されると, ランプ内は㨁ちにランプ管壁温度で決まる水 銀蒸気圧で飽和される (図 7 参照). この水銀蒸気は, その圧力 に応じ排気助成作用として排気系に排出されるが，一部は水銀滴 


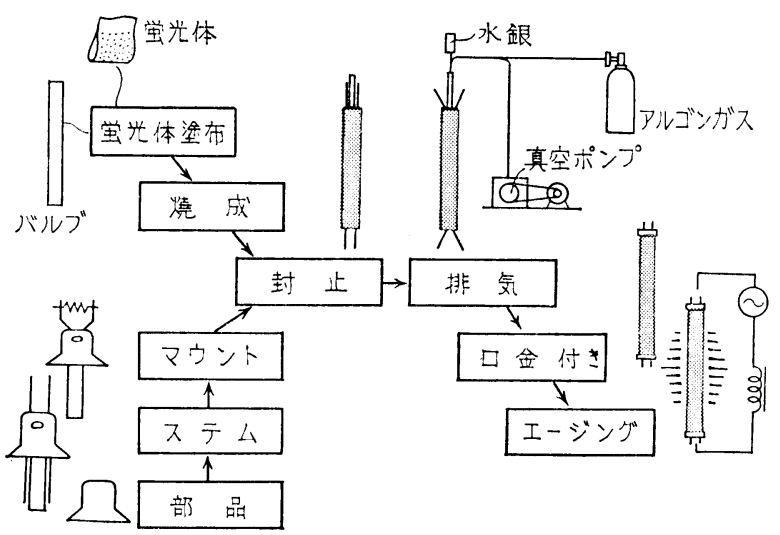

図 6 监光ランプの製造工程図

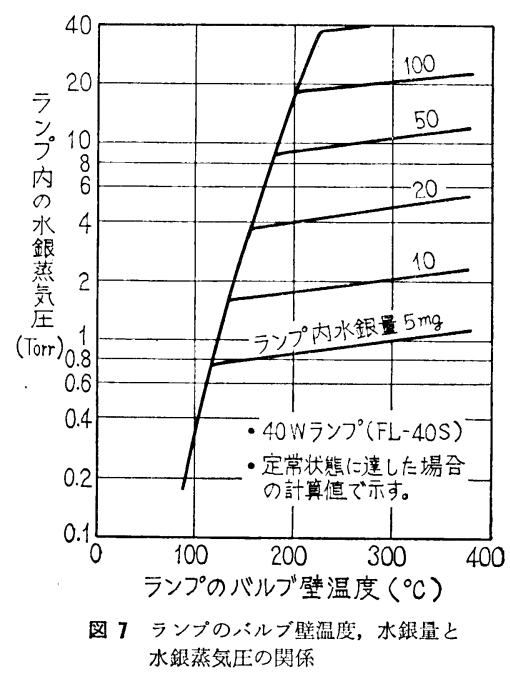

下器内の排気管部分などのより冷却された部分に凝集される.し たがって，排気最終工程での封入水銀がこれら凝集水銀に接触補 足されたり，凝集水銀を伴ってランプ内に封入される.このよう な水銀の挙動のため，実際にランプ内に封入される水銀量は大き な変動を示与．たとえば， $40 \mathrm{~W}$ ランプの場合の必要量は前述の と抢り $10 \mathrm{mg}$ 程度であるが，上記理由により従来は $5 \sim 60 \mathrm{mg}$ 程 度封入されていた ${ }^{13)}$.この実態を品質面からみると次のようにい える.

（a）省資源的に好ましくないまた，寿命後の廃车物として必 要以上の量は低減の妱力が必要である.

（b）過剩な水銀を含先場合, ランプ点灯中管壁の冷却部分に水 銀が凝集し外観上好ましくないのはもちろん， ランプ内にネサ膜 を有するラピッドスタート形ランプでは，ネサ膜破壊に結びつき 異状光束劣化を起こす場合がある14.

\section{（2）封入ガス圧の变動要因となっている}

希ガスであるアルゴンは, 排気工程の最終段階で封入される が，前述のと抢り封入水銀量の変動に起因してランブ内の水銀蒸 気压が変動しており，この状態で通常 2 〜 Torr のアルゴンを 封入しても，ランプ排爸管が溶封される前に一部のアルゴンが排 出され，結果的にランプ内のガス压が一定にならない（図 8 参 照).

一方，アルゴン压はランプの性能に大きな関連を持って拈り， 一定の最適值が存在する. 主な性能への影響程度は次のと拈りで ある.

(a) 寿命への影響は, アルゴン压 \pm 0.1 Torr に対し寿命約士

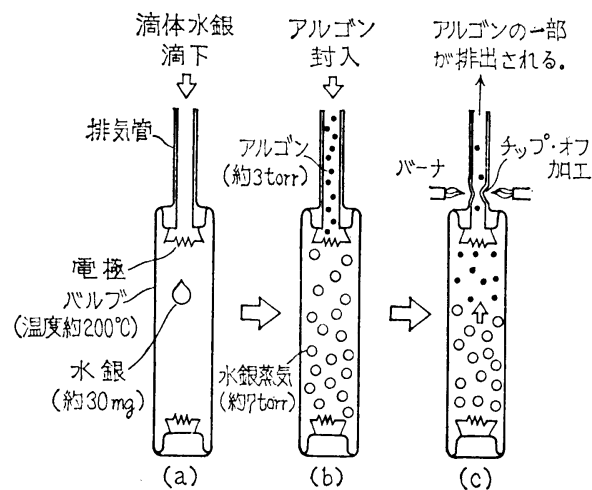

图 8 排気工䄳中での水銀滴下による封入フルゴ ンの変動への影暳原因説明図

（a）水銀滴下部 (b) アルゴン封入部 (c) チップ・オフ部

1,000洔問の変動になる.

(b) 光束への影響は，アルゴン压士0.1 Torr に刘し光束約干 $0.5 \%$ 変動になる。

従来製法では，前記の理由によりガス压がほぼ士0.2 0.3 Torr の変動をする。これは製品個々にみると寿命のばらつき範 囲 $4,000 \sim 6,000$ 㭙間に相当与る.この值は先際のランプ目集団の 寿命変動 ${ }^{15)}$ のほぼ $1 / 2$ を占めていることになる.

以上のとおり, 従来製法は寿命, 光束などの信頼性の面で改善 の必要がある.そして，この水銀粒滴下に基因する影響を除くに は，(1) 水銀による排父助成に代わる排気方法の開発，(2) 水銀 量を高精度で封入するか，水銀蒸気の影響のない水銀封入法の開 発が必要となる。

\section{3 各種水銀封入方法}

蛍光ランプが実用化されて以来，水銀の封入はいわゆる液状の 金属水銀を粒状にして封入する方法が採用されていたが，ここ10 年汪どの間に各種の改良方法が奏用化されてきた。これらの水銀 の封入方法は主に次の引つに分類できる.

\section{（1）水銀粒直接封入法}

液状の水銀粒を重力を利用あるいは，封入ガスなどにより封入 する方法であり古くから実用され，現在でも広く利用されてい る. 図 9 は代表的な封入装满の構造を示すが，分離した水銀粒 が排気管ストッパ部などに一部付着したり， $40 \mathrm{~W}$ ランプの必要 量約 $10 \mathrm{mg}$ (直径約 $1 \mathrm{~mm}$ の球) 程度では, 排父管壁に付着する などの欠点がある.

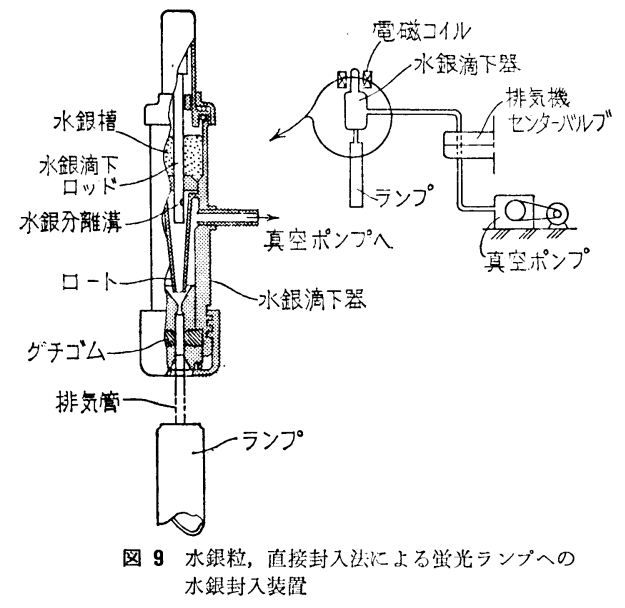

（2）水 銀 合金法

水銀を金属との合金とし電極などに取り付け，排気完了後高周 波などの外部加熱で必要な液体水銀を分湤与る方法であり，古く 


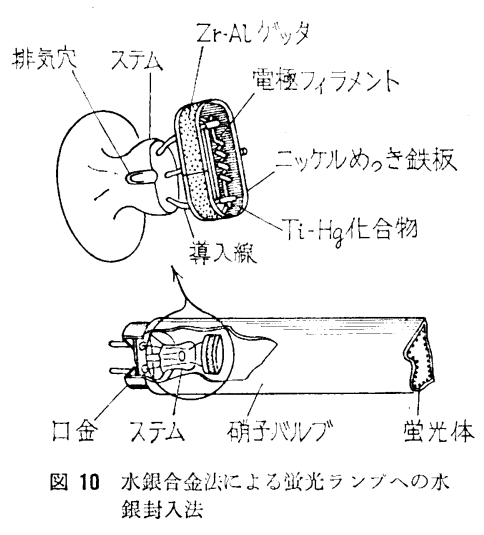

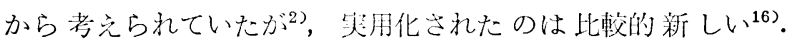
図 10 はこの梅造例を示す．この方法は水銀を正確に定星封入す る方法としては優れている.

\section{（3）水銀カプセル法}

液体水銀を硝子などのカプセルに封入し，これを電極などに取 り付壮，排父完了後何らかの方法でこ秃を破り水銀学分離する方 法であり，实験的にはやはり古くから考兄られているが ${ }^{10)}$ 実用化 は新しい.17). 図 11 は構造例を示与。この方法も水銀合金法と同 じ利点がある.

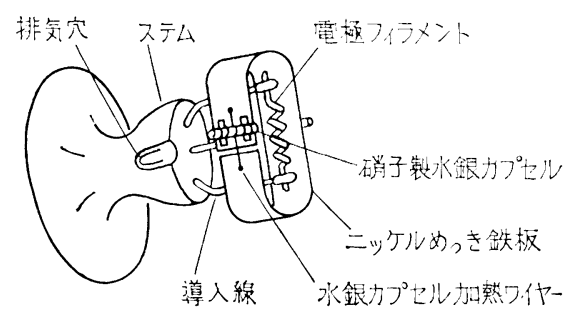

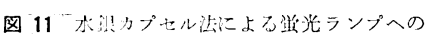
水銀封入法

\section{4. 蛍光ランプヘの水銀合金の応用}

\section{1 水銀合金法の概要}

水銀合金を応用する製法とは液体水銀を使用せず，水銀合金な どの金属固形物をあらかじめ電極付近敒り付けておき，ランプ

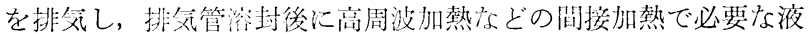
体水銀艺ランプ内に分離する方法である。

この方法は排父工程では液体水銀は伐用しないため, 前述の液

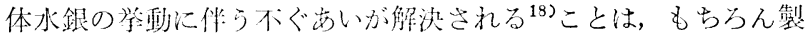
造環境もより改善さ机る ${ }^{19}$ ことになる。一方，この水銀合金法を 採用与るにあたっては，大別して次のような新しい技術が必要に なる。

(1) 水銀合金材の開発

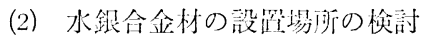

(3) 排気プロセスの変更

（4）水銀分皠法の開発

\section{2 水銀合金材について}

监光ランプ用の水銀合金材としては, 次の性能が要求される.

(1) 排気工程終了までに加熱される温度約 $500^{\circ} \mathrm{C}$ 以下では水 銀が分離せず，それ以上の況度では可及的低い温度で分離する。

（2）水銀分離のための加熱で放出される不純がスを，完全に再 吸収するゲッタ材を有する棈造であること.
（3）必要量の水銀を含有すること.

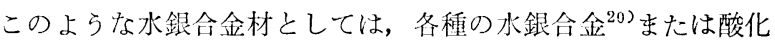
水銀とダッタ材の組久合わせが考学られる゙3.いずれでも実用可 能なものが製作できる。一例を表 1 に示す。

表 1 蛍光ランプ用水銀合金材の例21)

\begin{tabular}{|c|c|c|}
\hline & 项 & 队 \\
\hline 仕 栏 & 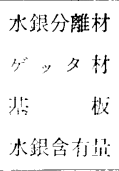 & $\begin{array}{l}\mathrm{Ti}-\mathrm{Hg} \text { の金属間化合物 } \\
\mathrm{Zr}-\mathrm{Al} \text { 合点 } \\
\mathrm{Ni} \text { めっき } \mathrm{Fe} \\
4.5 \pm 0.5 \mathrm{mg} / \mathrm{cm}\end{array}$ \\
\hline 待 性 & 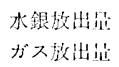 & $\begin{array}{l}3.0 \pm 0.5 \mathrm{mg} / \mathrm{cm} \\
900^{\circ} \mathrm{C} \text { 加熱で垠大 } 7 \text { Torr } \cdot \mathrm{cc} / \mathrm{cm}\end{array}$ \\
\hline
\end{tabular}

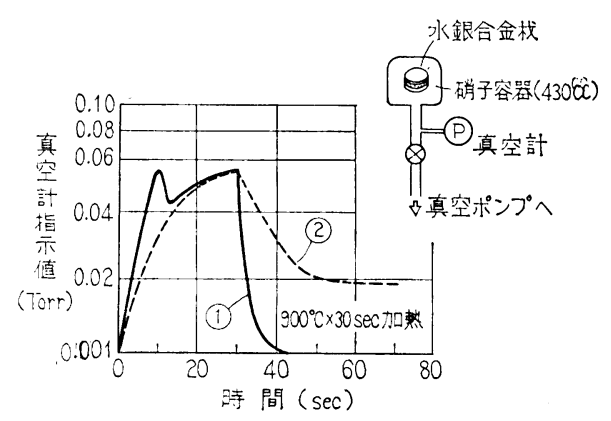

(1) $7 i-H_{g}$ 化合物 (水銀放出量 $3 \mathrm{mg} / 10 \mathrm{~mm}$ )

$$
\begin{aligned}
& \text {-18h 年長 } 45 \text { 合金ゲッ夕 } \\
& \text { N18-h 全長 } 45
\end{aligned}
$$

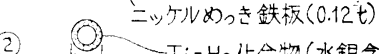

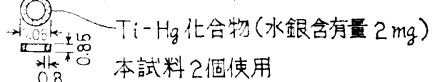

图 12 水銀合金材の加熱に上るガス故出と吸収

水銀合金材の吸藏ガスの放出再吸収特性は 図 12 のとおりで あり，蛍光ランプの体積の大小によって放出ガスが完全に再吸収 されるためゲッタ材にある必要面積が要求される。すなわち, 一般的には体積も大きく必要水銀量も大であるランプには，いわ ゆる带状の合金材が適し，小型ランプでは，従来から数字表示管 などに使用されているリングタイプが使用可能となる.

\section{3 水銀合金による蛍光ランプの製法}

\section{(1) ランプ構造の選定}

水銀合金材をどの部分にどのように取り付けるかは特性，およ び生産技術上の利欠点を加味して足める必要がある，現実には紗 光ランプ全品種に共通な構造は困難で岕り，図 13 に示す三つの タイプで全品種をカバーできる。

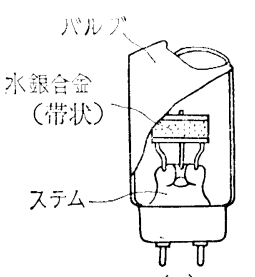

(a)

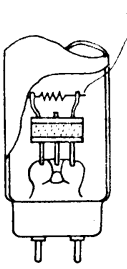

(b)

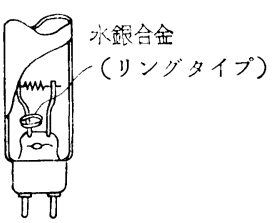

(c)
图 13 行種办銀合金の取付以位置の例

(a) ラピッド・スタート形 (b) グロースタート业

(c) 小ワット形

ランプ点灯中の水銀合金材の温度はほ注 $300^{\circ} \mathrm{C}$ 以上の場合，ゲ ッタ材の酸化性ガスの吸収能力が良くなり, 酸化第 2 水銀などに 上る蛍光体の着色や，スポット状黑化が抑制されてくる．この点 から一般に高出力タイプのランプほどゲッタ効果が顕著になる. 


\section{(2) 排気プロセスの変更}

液体水銀の封入機構を有する従来の排気系統では, ランプに必 贾な水銀を封入する以外に，排気操作中に液体水銀を皆入し，こ の水銀蒸気によって，ランプ内のガスを排出するいわわる排炎盺 成作用を行ならことができる。この方法は排父管を一端に沙けた

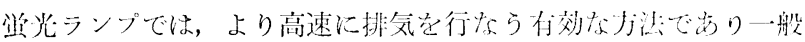
に広く採用されていた。

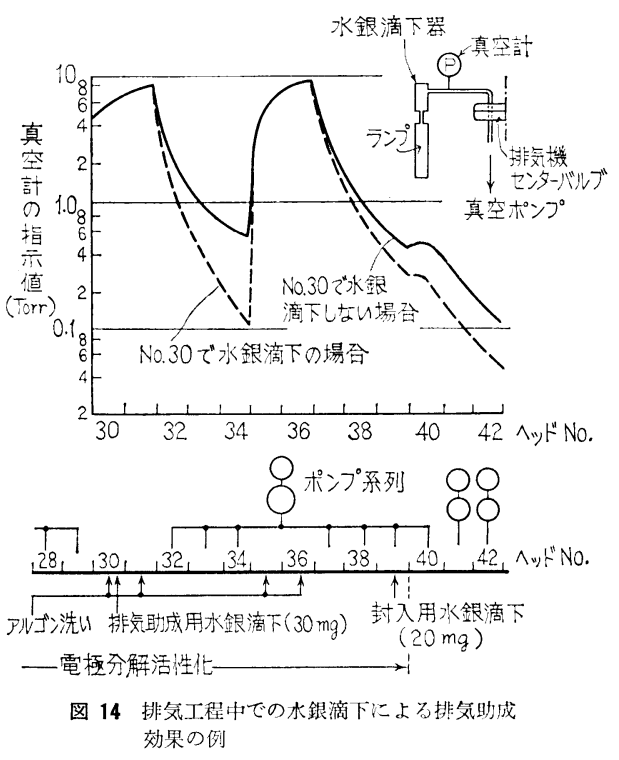

水銀合金法では液体水銀の封入機構を有しないため，上范に代 わる排父方法を採用する必要がある. 図 14 は水銀蒸気に上る排 気助成の有然による，排気機各へッドの真空度变化の記録例であ る. この排気助成に代わり得るものとして, 排気中にアルゴンガ スを封入しランプ内の分解ガスなどと混合，真空ポンプの能力の 高い真空度领域で排気するいわゆるアルゴン洗い法を改善する力 法がある. 表 2 はアルゴン洗い压と分解ガスであるCO の残量 との関係であるが，圧力を10２0 Torr とすることで基本的には 十分補うことができる.もちろんこのような方法では, アルゴン による電極冷却作用のため, 荫電極炭酸塩の分解のバランスにつ いて考虑する必要がある。

表 2 排気工程中のアルゴン洗い压力とテンプ内残留ガスの閂係

\begin{tabular}{c|c|c|c|c|c}
\hline ホ銀による排気助成 & あり & \multicolumn{4}{|c}{ な } \\
\hline アルゴン洗い压力 (Torr) & 3.0 & 3.0 & 10.0 & 20.0 & 30.0 \\
\hline ランプ内残留 $\mathrm{CO}$ 量 (相対值) & 1.0 & 4.7 & 1.3 & 1.0 & 0.8 \\
\hline エーシシング前起動電压 (V) & 169 & 203 & 176 & 170 & 167 \\
\hline
\end{tabular}

(注) 1. アルゴン洗い回数は, 炭酸塩分解䦥始後 4 回.

2. CO 量测定は質量分析計に上る。

\section{（3） 水銀分離法の開発}

水銀合金材から水銀を分離するには，一定温度で一定時問加熱 が必要である.この加熱には高周波誘導加熱が適している.この 分離工程を図 15 に示すが，ここでは次の 2 点が重要なプロセ ス条件となる.

\section{(a) 加熱時のバルブ温度}

加熱により水銀合金材からは各種のガスが放出されるが，バル ブ温度が低い場合は，ゲッタ材がガス吸收するまえに一部が蛍光 体などに吸着されランプ特性に㴗影響する。また，温度が高過ぎ る場合は，排気管溶封後も内部でバルブ硝子などからのガス放出 が続き真空度を低下させる，最適值は200〜 $300^{\circ} \mathrm{C}$ にる。

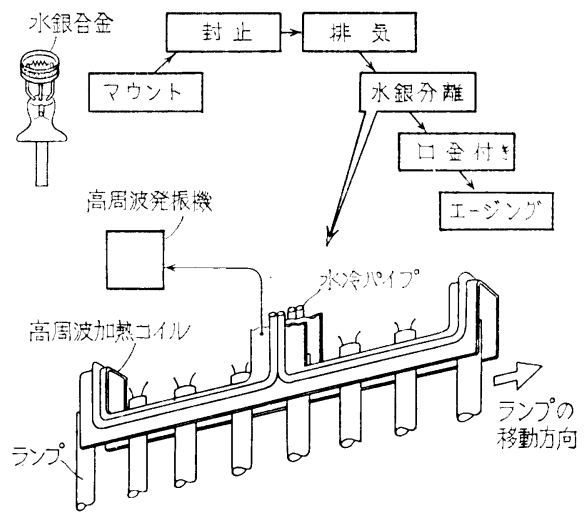

图 15 高周波に上る水银分離工程

\section{（b）高周波電界の強さ}

水銀合金材から水銀の放出が始まった場合，高周波電界が強い と水銀原子が励起され，ランプはいかゆる高周波放電を起こす。 この上らな高周波放電状態では, 水銀合金材から放出されたガス の5占, 主に水素が活性化され些光体に吸着し発光効率を低下さ せる ${ }^{22)}$. 西た，酸化錫膜を有するピッドタイプのランプでは，酸 化錫膜が環元され黒色の二価あるいは金属錫となり, 初期光束を 低下させる. 電界の強さの限界は高周波コイルの形状やランプの 設計で異なるが，潘ぼ高周波コイルの電压で $100 \mathrm{~V}$ 以下が好李し ${ }^{23)}$.

\section{4 品質への効果 \\ （1）封入水銀量の精度向上}

水銀合金法では, ランプ内に封入される水銀量は合金材に含有 される水銀量と加熱温度, 時間で主に洪まる.たとえば $10 \mathrm{mg}$ を 中心に封入する場合の変動要因について侾えると, 表 1 の合金材 を全長 $47 \mathrm{~mm}$ のリング状に加工取り付汁た場合の, 放出可能水 銀量は 11.7〜 16.4 mg となる. 一方, 加熱時間は製作工程上一定 とし，加熱温度（高周波出力）により水銀放出割合が变化する. したがって高周波出力をコントロールすることにより，ランプ内 への水銀放出量を制御することになる.図 16 は実際のランプで の水銀量分布例である. この例では封入量は従来法の $1 / 3$ とない ている.また，従来法でもアルゴン洗い法の改善で水銀による排 気助成を止めることで $2 / 3$ となることがわかる。

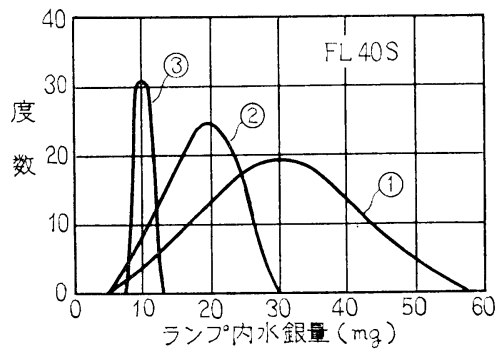

図 16 各種水銀封入法によるランプ内水銀 量の分布

1) 水銀粒滴下法（皮銀による排気助成 あり) $\bar{X} 30, \sigma 7$

(2) 水銀粒滴下法（木銀に上る排気助成な ᄂ) $\bar{X} 18, \sigma 4$

(3) 水銀合金法(皮銀による排気助成なし) $\vec{X} 10, \sigma 0.7$

（注）水銀星の測定は次による. 水銀粒滴下法：ランプ内の水銀を採集し その置をジチゾンクロロホルム抽出法で 測定, 測定䛊差は $10 \%$ 以内. 水銀合金法： 水銀放出前後の重是差を水銀量とする。 䛊差 $5 \%$ 以内、 


\section{（2）封入ガス圧の精度向上に伴う特性改善}

水銀合金法では, 前述のとおり水銀蒸気の挙動に伴ら封入ガス 厄への影響がない.したがって封入がス压の精度は図 17 程度 に向上する。このため封入ガス圧に影響される特性，たと党ば絶 対寿命の信頼性が向上する．図18はとの一例である.

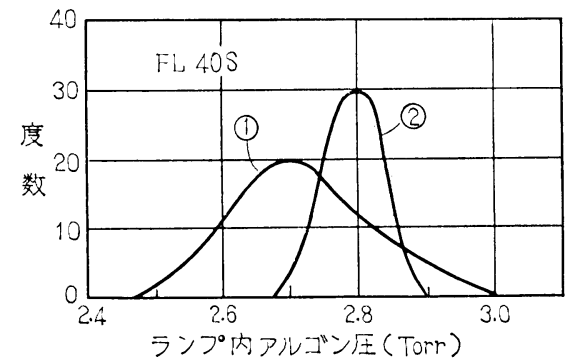

图 17 水銀封入法に上るランプ内アルゴン匠の分布 (1) 水銀粓洐下法 (アルゴン无設計値 2.7 Torr) $\bar{X} 2.7 \sigma 0.12$

(2) 水銀合金泣（アルゴン代設計值 2.8 Torr) $\bar{X} 2.8 \sigma 0.03$

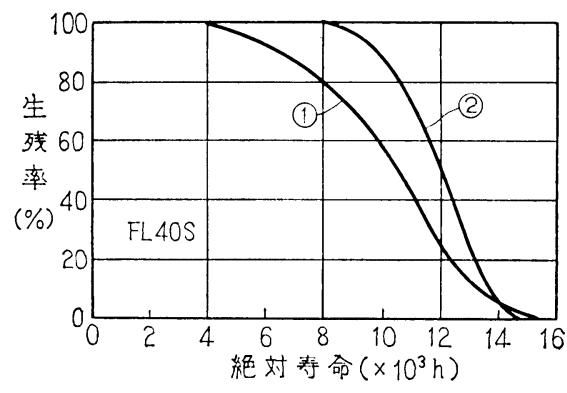

图 18 水銀封入洁に上るランブ緦対寿命の分析 (1) 水銀料滴下法（封入アルゴン任 2.7 Torr) (2) 水銀合金法（封入アルゴン压 2.8 Torr)

（注）寿命は $3.0 \mathrm{~h}$ 点灯 $0.5 \mathrm{~h}$ 激灯サイクルによる. (2)の試料数は 75 本.

\section{（3）その他の特性改善}

水銀合金法では，前述のとおりゲッタ材を併用しているためラ ンプ点灯中ランプ内の酸化性:ガスが吸収され, その結果, 光束維 持率が改善される. 改善の程度は高ワットのランプほぞ顕著であ クランプの相対寿命も1.2 1.4 倍程度の改善が期待できる ${ }^{24)}$.

\section{5. 今 後 の 動 向}

蛍光ランプは，現有光源の中でもきわめて有用なランプである が，このランプの水銀量の精度向上は単なる品質の向上にとどま らず，省資源の面からも引き続き努力を要する課題である。本報 は，一つの解決策である水銀合金法の実用化汇関するものである

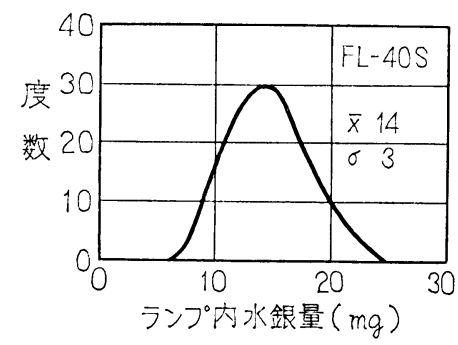

図 19 最近の水銀粒滴下法によるラン プ内水銀量の分布

（注）水銀による排気助成なし，木銀粒 $20 \mathrm{mg}$ 滴下， 水銀量測定はジチゾンクロロホルム抽出法によ る。
が，同じような効果の得られる水銀カプセル法も一部実用化され ており,さらに単にランプ内の水銀量の上限に関する改善に限れ ば，水銀粒直接滴下法でも機械精度の向上などで，現在では 図 19 程度の精度が得られている.この実績では，たとえば水銀 合金材 $47 \mathrm{~mm}$ の水銀含有量 (表 1 参照) 19 24 mg と注注同程度 の絶刘值以下に拈さえられている.もちろん水銀蒸気の挙動に伴 万品質上の改善が必要であり, そのため, (1)水銀封入法の一層の 改善, (2)ランプ内の水銀消費プロセスの解明が今後の課題である といえる.

\section{6. 結言}

水銀を必要としない営光ランプに代わり得る高効率の実用光源 の開発見込みが薄い現在, 営光ランプの品質向上にとどまらず, 省资源面からも定水銀の新しい製法の開発が要求される．水銀合 金法も現実的に有効な解決策であり，またその技術は他の水銀封 入法にも応用が広い.

現在，监光ランプは単なる直管や円形状のものにとどまらず， 電球形などさまざまな応用展開が行なわれている25). 水銀の封入 は，これらの基本技術としてますます重要な課題であるといえ る.

\section{参 考 文 献}

（1）電球工業会報 302 (昭58.4)

(2) 米国特許 : $3,385,644$ (1966)

(3) 特公昭 48-12385

(4) 特開昭 52-146075

(5) Giorgi, T. A., dellaporta, P.: Residual Gass in Electron Tubes (1972) I23

(6) 特開昭51-172708

(7) 大森：照学誌 64-1 (昭55) 30

（8）照明学会：けい光ランプの水銀代替に関する調査研究報告 書 (昭49)

（9）照明学会：照明のデータブック（昭45） 107

(10) 真室：照学誌 42 (昭33) 135

(11) 特公昭51-38191

(12) 社日本電球工業会：昭和 52 年度電気器具の有害物質除去に 関する調查研究報告書（昭53.5）

(13)（祖日本電球工業会：蛍光ランプ処理対策調査報告書(昭49) $24 \sim 25$

(14) 広田ほか：照学誌 60-2（昭51） 72

(15) 照明学会：照明のデータブック（昭45） 114

(16) 広田活か：昭49照学東京支部大会（昭49）3

(17) 電波新聞 昭52.2.1

(18) Hirota, T. et. al.: J. Light \& Vis. Env. 1-1 (1977) 1

(19) Rabusin, E., Perego, R.: Light. Res. Tech. 15-1 (1983) 32

(20) たと党ば特公昭49-5659

(21) SAES社：GEMEDIS 仕様（St 101, St 505）による.

(22) Тугелд, Е. М.: Светотекника 2-7 (1963)

(23) 特公昭55-46617

(24) 広田泀か：昭50照学全国大会（昭50）16

(25) 広田, 鈴木：照学誌 67-11（昭58） 552

（受付1983年11月 9 日） 